\title{
ANALYSIS OF THE INFLUENCE OF CUTTING PARAMETERS ON SURFACE ROUGHNESS IN LASER CUTTING PROCESS OF TUNGSTEN ALLOY USING CONTROL CHARTS
}

\author{
Derzija Begic-Hajdarevic, Branko Vucijak, Mugdim Pasic, Izet Bijelonja
}

Original scientific paper

The paper presents analysis of the influence of cutting parameters on surface roughness during $\mathrm{CO}_{2}$ laser cutting process of tungsten alloy by using nitrogen as assist gas, based on control charts made by statistical process control (SPC) approach. Dependent variable is surface roughness, while independent variables are laser power and cutting speed. The control chart used within this paper is a variation of the moving means chart of experimental data samples, that calculates mean and range values using the three consecutive individual values. Applying the criteria often used in the SPC methods for the assessment of "out of control" situations, it may be inferred that increasing the cutting speed leads to worsening of control status for the process with lower laser power used.

Keywords: control charts; $\mathrm{CO}_{2}$ laser cutting; surface roughness; statistical process control; tungsten alloy

Analiza utjecaja parametara rezanja na hrapavost površine pri rezanju laserom legure volframa uporabom kontrolnih karata

Izvorni znanstveni članak Rad predstavlja analizu utjecaja parametara rezanja na hrapavost površine tijekom $\mathrm{CO}_{2}$ rezanja laserom legure volframa uporabom nitrogena kao pomoćnog plina, zasnovanu na kontrolnim kartama izrađenim pristupom statističke kontrole procesa. Zavisna varijabla je hrapavost površine, dok su neovisne varijable snaga lasera i brzina rezanja. Kontrolna karta koja se koristi u ovom radu je karta promjenjivih srednjih vrijednosti, koja potrebne srednje vrijednosti i raspone uzoraka proračunava uporabom tri uzastopne pojedinačne mjerne vrijednosti. Uporabom kriterija koji se često koriste $u$ metodama statističke kontrole podataka za provjeru da li je situacija "izvan kontrole" može se zaključiti da povećanje brzine rezanja vodi k pogoršanju kontrole procesa s manjom uporabljenom snagom lasera.

Ključne riječi: $\mathrm{CO}_{2}$ rezanje laserom; hrapavost površine; kontrolne karte; legura volframa; statistička kontrola procesa

\section{Introduction}

Alloys of tungsten that include $90 \%$ to $97 \%$ of pure tungsten with combination of nickel and copper or with nickel and iron are considered as heavy metals. These alloying elements improve ductility and machinability in comparison to non-alloyed tungsten. Because of their high density, these alloys find wide applications as centre of gravity adjusters, radiation shields, kinetic energy penetrators, and so on [1]. Laser beam cutting of tungsten alloys is very interesting and always a challenging task because the melting temperature of these alloys is too high to be fabricated by the thermal process.

Laser cutting is a thermal process without mechanical contact with work piece. Absorbed energy of laser beam heats the work piece and creates molten state of work piece in the cutting area. Molten material can be removed using assist gas that is co-axial with the laser beam. Laser beam cutting is a flexible process and it offers a good solution that is indeed more associated with material properties such as thermal conductivity and specific heat as well as melting and boiling temperatures. The $\mathrm{CO}_{2}$ laser is used for cutting different materials such as ceramics, metals, plastics, composites etc. [2]. Productivity and components quality of laser cutting are of major concern to manufacturing companies. Both productivity and components quality are treated by the selection of cutting parameters. These parameters are different for different type of materials and thickness of materials. Optimization of the parameters during laser cutting process is important to improve the quality of produced components. Usually neural network and statistical approach are used for development of machining process models [3, 4]. Many different aspects of laser cutting are used to develop prediction model of important characteristics of quality [5]. The influence of technological parameters on the final cut quality during cutting the cobalt alloy by a continuous $\mathrm{CO}_{2}$ laser was analysed in [6]. Laser cutting parameters such as power, speed of cutting, pressure of assist gas and focus position are examined while cutting different type of materials using $\mathrm{CO}_{2}$ laser system. Optimization is done using numerical and statistical methods $[7,8]$. The use of the $\mathrm{CO}_{2}$ laser ensures better process characteristics during cutting of low-carbon steel sheets, while the use of the fibre laser is more effective for cutting stainless steel sheets with nitrogen used as a process gas [9]. Influence of carbon nanotubes and process parameters while performing $\mathrm{CO}_{2}$ laser cutting of multi-walled carbon nanotubes/poly methyl methacrylate composite is analysed using analysis of variance method [10]. Modelling of relation between process parameters and characteristics of quality during $\mathrm{CO}_{2}$ laser cutting of tungsten alloy is performed using artificial neural network [11]. Proposed prediction model can be a practical tool for surface roughness and kerf width prediction.

Review of the literature shows that the research in the field of laser cutting of tungsten alloy is still limited. Hence, this paper reports an evaluation of surface roughness during laser cutting of tungsten alloy plate having nitrogen used as assist gas, based on moving mean charts made by statistical process control (SPC) approach.

\section{Use of statistical process control}

Methods of statistical process control are effective tools to control the quality in a process of production or even service provision. Their application aims at continuous improvements in the product quality with maintaining the lowest level of variations in the 
production process. It generally consists of three phases as follows:

- Creation of the process flowchart, that presents individually separated process steps, functions and responsibilities;

- Measuring (individual at lower scale, samples at larger) - it is recommended to implement measurements at regular intervals, so as to secure new measurements every time there is change in phase, function, responsible person and similar in the process;

- "Control chart(s)" preparation that will enable recognizing "Pareto glitches" and their assignable causes, aiming to remove such special causes of variations.

Any process has its own built-in variations that cannot be removed without changing the process itself. What the control charts are searching for are special or assignable causes of variation that can be recognized and should be removed. Control charts are the best tool enabling distinguishing these variation types and thus providing the best response for the process control, including avoidance to unnecessary reactions.

Statistical process control gives answers to the following key questions: "Is the observed process under control", and "What is the inherited level of the process variability". While the response to second question defines the process capability, the first one evaluates if there are any assignable causes of variation or only common causes are present.

Any control chart defines three areas where the measurement can belong. Middle area shows that the process is properly running and thus is under control. Neighbouring areas, both above and below the middle one, send a warning that there could be some discrepancy to the natural process and that higher level of attention is needed for the next data. Outside areas, above and below the forms ones, are clearly showing that assignable cause (or causes) of variation happened before the data was taken and indicates that the process got out of control.

The SPC methods are used today for different problems like healthcare [12], software processes [13], statistical inference at work [14], even climate change assessments [15, 16] and others; however, its use for evaluation of cutting processes is still limited.

\section{Experimental procedure}

$\mathrm{CO}_{2}$ laser system is used to perform experiments. Nominal power of the laser system is 2000 W. $92,5 \%$ pure tungsten alloy plate with combination of nickel and iron and $1 \mathrm{~mm}$ of thickness is used for the experimentation. Lens focus length in experiment is 127 $\mathrm{mm}$. As assist gas nitrogen is used and brought coaxially with the laser beam via a nozzle with $2 \mathrm{~mm}$ diameter. During the experiments the following parameters are considered as constants: nozzle distance, position of focus point and pressure of assist gas. Optimal values of the parameters are chosen from the experimental study performed in [17].

Two input cutting parameters, laser power and cutting speed, are selected for this research. The values of cutting speed and laser power are depicted in Tab. 1.
Table 1 Process parameters and their values

\begin{tabular}{|l|c|}
\hline Laser power $(\mathrm{W})$ & $1500,1750,2000$ \\
\hline Cutting speed $(\mathrm{mm} / \mathrm{min})$ & $1000,1500,2000$ \\
\hline Assist gas type & Nitrogen \\
\hline Pressure of assist gas (bar) & 15 \\
\hline Focus position (mm) & $-0,5$ \\
\hline Nozzle distance (mm) & 0,75 \\
\hline
\end{tabular}

The controlled parameter is the surface roughness. Surface roughness on the cut surface is measured using a Taylor-Hobson instrument. As roughness parameters, average roughness $R a(\mu \mathrm{m})$ is considered. Surface roughness is measured at 20 different places along the cut approximately in the middle of cut thickness.

\section{SPC moving mean charts for laser cutting data}

SPC control charts for larger amount of data available are based on relevant sampling practice. But when the data availability is limited, conventional mean and range charts should be replaced with the moving mean and moving range charts. Individual charts are another option for low number of process data, where the decisions are often supported by the last data obtained. Data grouping, what is a strategy of moving mean and moving range charts, allows better-grounded decision making [18]. This paper uses the approach of moving average mean, where such charts use the available data in a different way, which could be preferred since the calming effect on the process should be expected. Grouping data together prevents reacting to individual results, what is important in avoiding possible over-control or unnecessary decisions, supported by such calming effect. Moving mean charts respond to the needs of limitedly available data processes (where this limitation is a consequence of expensive or time-consuming measurements, or even the high product price). The evaluation of the moving means and respective moving ranges with a selected grouping size of $n=3$ is presented in Tab. 2. For the next group of the three successive values, the earliest data in the group is discarded and replaced by the latest. This approach allows calculating and plotting a new mean value with every new individual value obtained, conveniently plotted at the last value acquisition time. In the below example $n$ $=3$, thus there are two data less for moving mean and range data than the initial number of individual values.

Table 2 Moving mean and moving range calculation

\begin{tabular}{|c|c|c|c|}
\hline Sample & Measured & $\begin{array}{c}\text { Moving } \\
\text { average }\end{array}$ & Moving range \\
\hline 1 & 3,0845 & & \\
\hline 2 & 4,7859 & & \\
\hline 3 & 5,5051 & 4,4585 & 2,4206 \\
\hline 4 & 5,5155 & 5,5103 & 0,0104 \\
\hline 5 & 6,0047 & 5,7601 & 0,4892 \\
\hline 6 & 5,9609 & 5,9828 & 0,0438 \\
\hline 7 & 4,6685 & 5,3147 & 1,2924 \\
\hline 8 & 3,7729 & 4,2207 & 0,8956 \\
\hline 9 & 4,8741 & 4,3235 & 1,1012 \\
\hline 10 & 5,3023 & 5,0882 & 0,4282 \\
\hline
\end{tabular}

In comparison with the charts with individual values, moving mean chart has a smoothing effect, which enables 
better recognition of trends and changes. Larger sample size provides better smoothing effect, but also provides for greater lag in following any trend, since the first mean appears only after first $(n-1)$ values. Moving mean chart rules say that the process is probably changed if [18]:

- there is a point outside the defined action lines;

- there are $(n-1)$ consecutive points between the defined action and warning lines - for this case if there are two consecutive points between the action and warning lines;

- there are eight consecutive points on the same side of the centreline for this case (or 2,5n in general case).
Upper and lower warning lines are set at two standard deviations above and below the centre line. Upper and lower action lines are set at three standard deviations above and below the centre line. Action and warning lines values are calculated using the following formulas (where the standard deviation is replaced by estimation using the moving range average):

$\mathrm{UAL} / \mathrm{LAL}=X \pm A_{2} R$ (for action lines) and $\mathrm{UWL} / \mathrm{LWL}=X \pm 2 / 3 A_{2} R$ (for warning lines),

where $X$ is average of the moving mean values, $R$ is average of the moving range values and for $n=3$ valid is $A_{2}=1,02$.

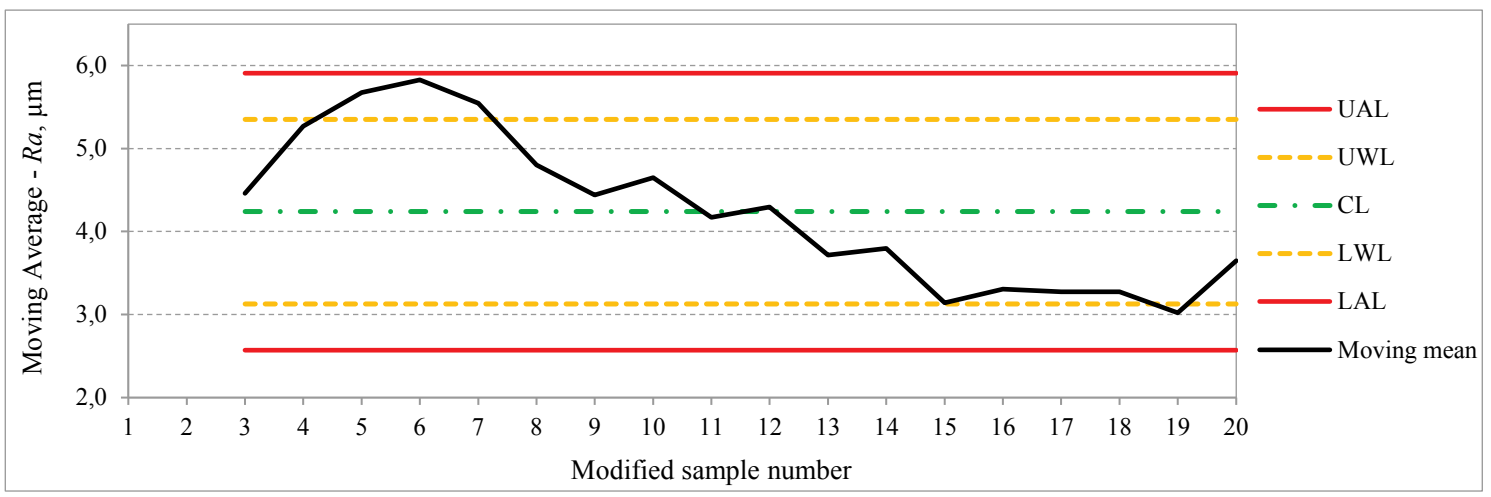

Figure 1 Moving mean chart for $1000 \mathrm{~mm} / \mathrm{min}$ cutting speed and $1500 \mathrm{~W}$ laser power

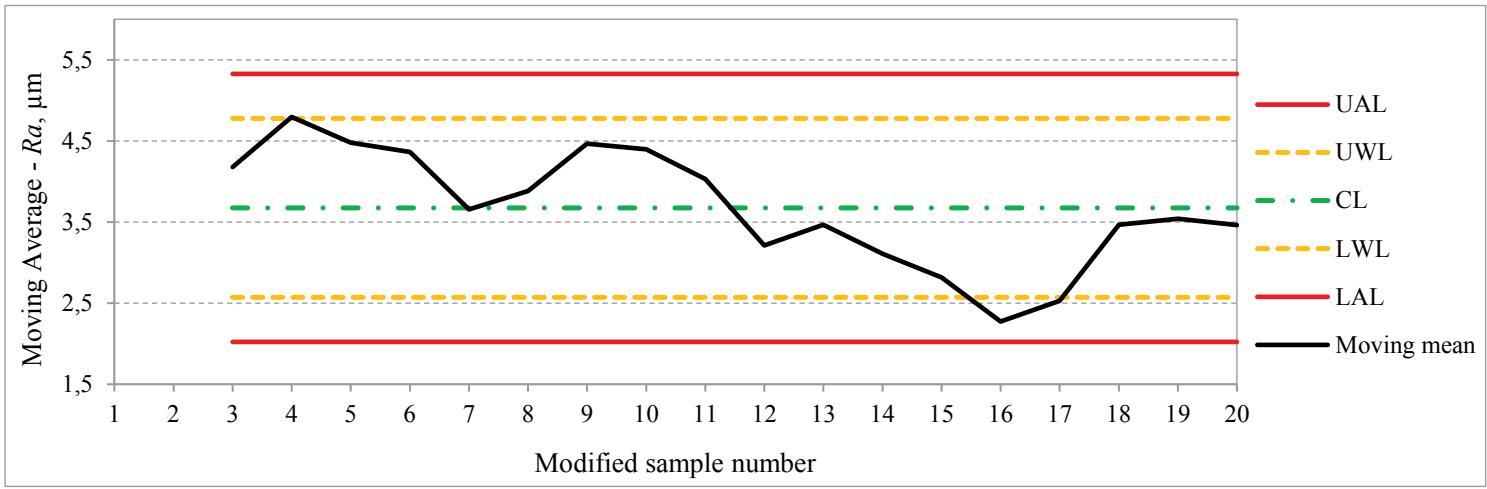

Figure 2 Moving mean chart for $1500 \mathrm{~mm} / \mathrm{min}$ cutting speed and $1500 \mathrm{~W}$ laser power

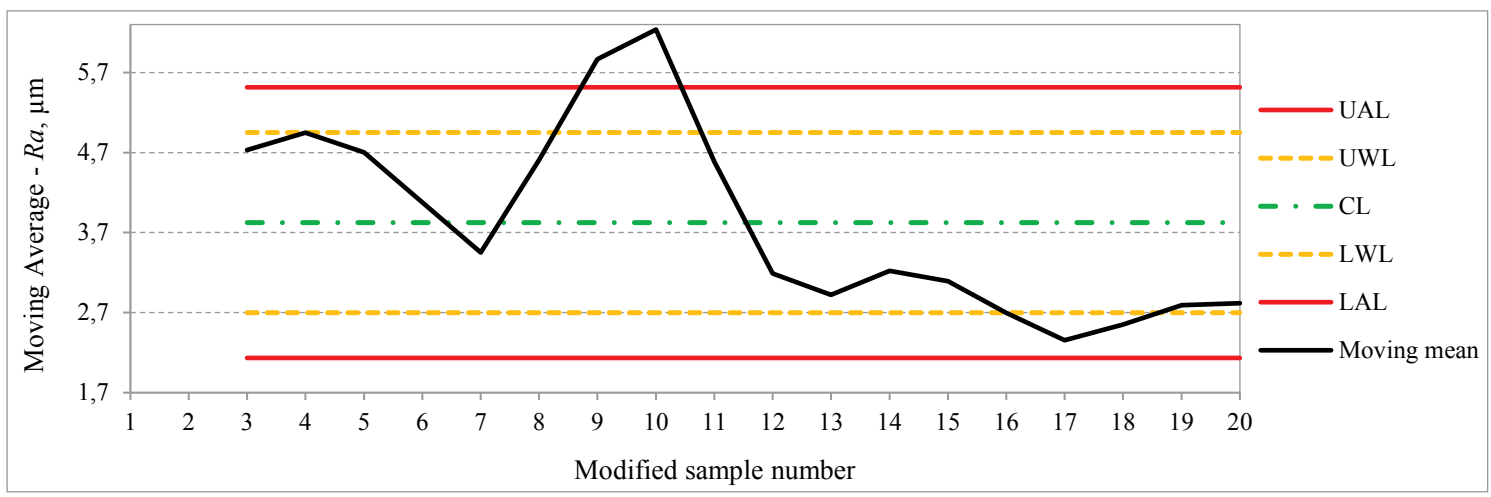

Figure 3 Moving mean chart for $2000 \mathrm{~mm} / \mathrm{min}$ cutting speed and $1500 \mathrm{~W}$ laser power

This research is based on experimental data in laser cutting of tungsten alloy by using different laser power and cutting speed such as: $2000 \mathrm{~W}$ laser power and cutting speeds for 1000,1500 and $2000 \mathrm{~mm} / \mathrm{min} ; 1750 \mathrm{~W}$ laser power and cutting speeds for 1000, 1500 and 2000 $\mathrm{mm} / \mathrm{min}$; so as $1500 \mathrm{~W}$ laser power and cutting speeds for
1000,1500 and $2000 \mathrm{~mm} / \mathrm{min}$. For each of the above listed 9 different cases 20 cuttings were made and related surface roughness was measured, resulting sequences of 20 measures were used to create moving mean control charts. Results are presented with the following charts. 
Fig. 1 relates to moving mean chart for $1500 \mathrm{~W}$ laser power and $1000 \mathrm{~mm} / \mathrm{min}$ cutting speed. It can be seen that there are no points of the chart outside of the area defined by action lines, but there are even three points above upper warning line and one below lower warning line, meaning that the process is not under control.

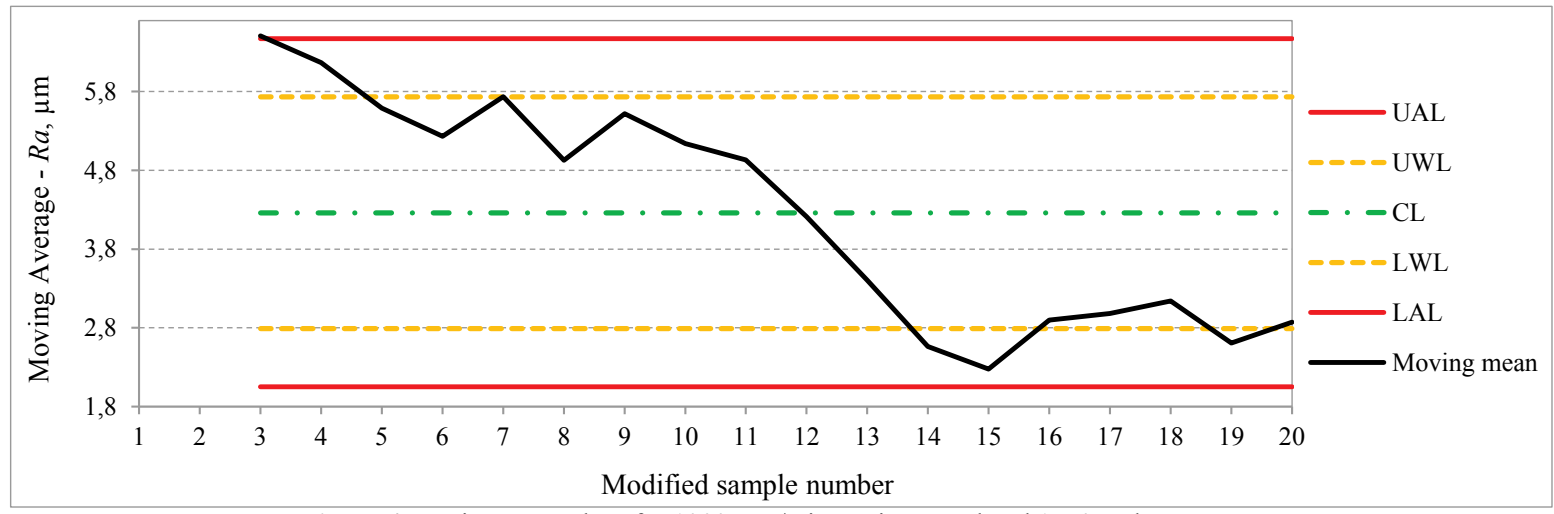

Figure 4 Moving mean chart for $1000 \mathrm{~mm} / \mathrm{min}$ cutting speed and $1750 \mathrm{~W}$ laser power

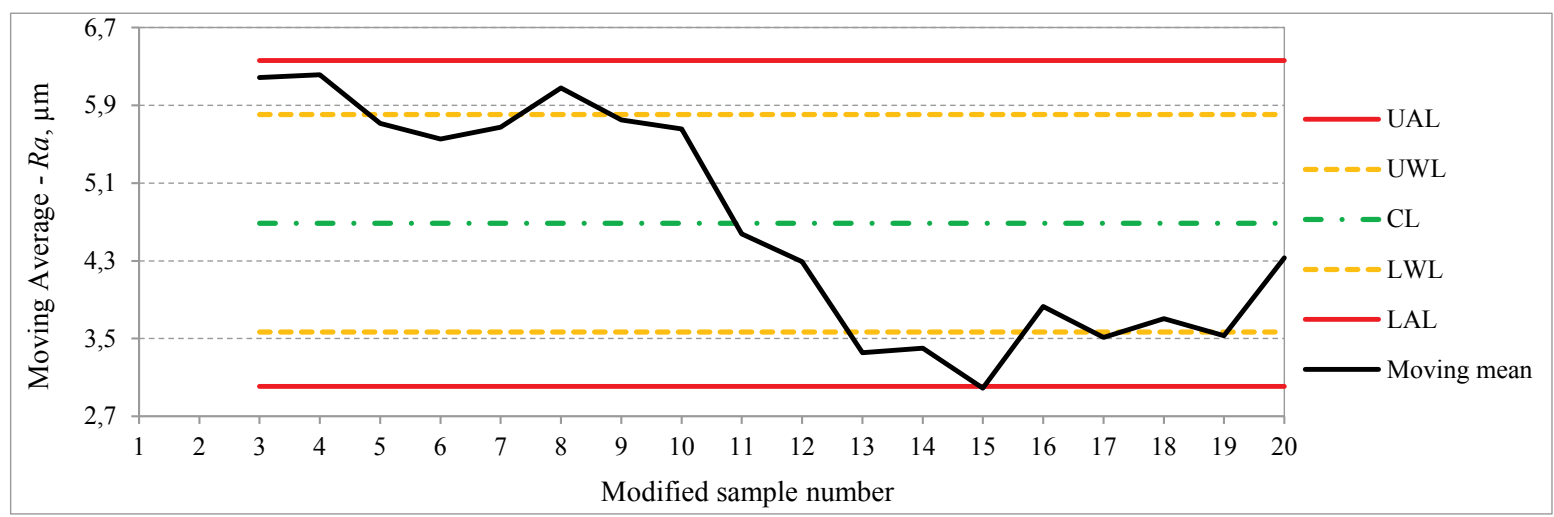

Figure 5 Moving mean chart for $1500 \mathrm{~mm} / \mathrm{min}$ cutting speed and $1750 \mathrm{~W}$ laser power

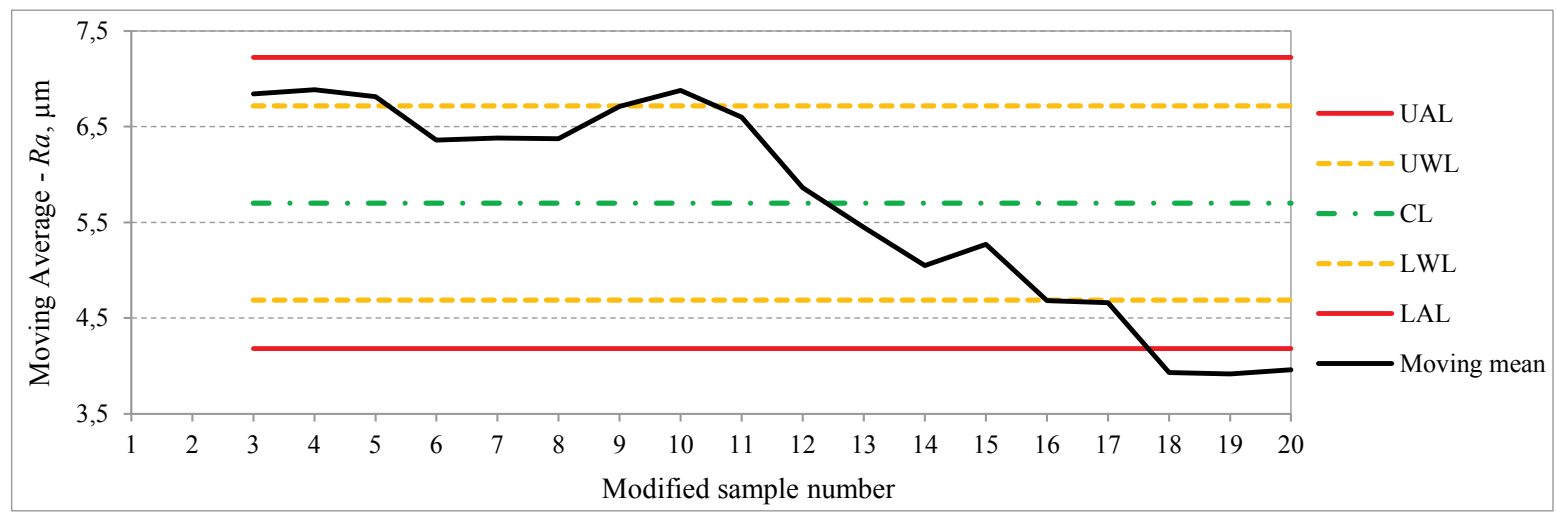

Figure 6 Moving mean chart for $2000 \mathrm{~mm} / \mathrm{min}$ cutting speed and $1750 \mathrm{~W}$ laser power

Figs. 2 and 3 also relate to $1500 \mathrm{~W}$ laser power and cutting speeds for 1500 and $2000 \mathrm{~mm} / \mathrm{min}$ - these charts show that there is one point above upper warning line and two below lower warning line for $1500 \mathrm{~mm} / \mathrm{min}$, while there are even two points above upper action line and three below lower warning line for $2000 \mathrm{~mm} / \mathrm{min}$, what is showing that increase of speed worsens process control. Figs. 4, 5 and 6 relate to $1750 \mathrm{~W}$ laser power and cutting speeds for 1000,1500 and $2000 \mathrm{~mm} / \mathrm{min}$ respectively. These charts show that one point is above upper action line, two above upper warning line and three below lower warning line for $1000 \mathrm{~mm} / \mathrm{min}$; also there are three points above upper warning line and four below lower warning line for $1500 \mathrm{~mm} / \mathrm{min}$ (with one additional point even below lower action line), so as there are four points above upper warning line, two below lower warning line and even three below lower action line for $2000 \mathrm{~mm} / \mathrm{min}$, what shows that increase of speed worsens process control and all three cases are not under control.

Finally, Figs. 7, 8 and 9 relate to $2000 \mathrm{~W}$ laser power and cutting speeds for 1000, 1500 and $2000 \mathrm{~mm} / \mathrm{min}$ respectively - these charts show that there are three points above upper warning line and one below lower warning line for $1000 \mathrm{~mm} / \mathrm{min}$; but no points are outside of the area defined by the two warning lines for either 1500 $\mathrm{mm} / \mathrm{min}$ or $2000 \mathrm{~mm} / \mathrm{min}$, and finally these processes are under control. 


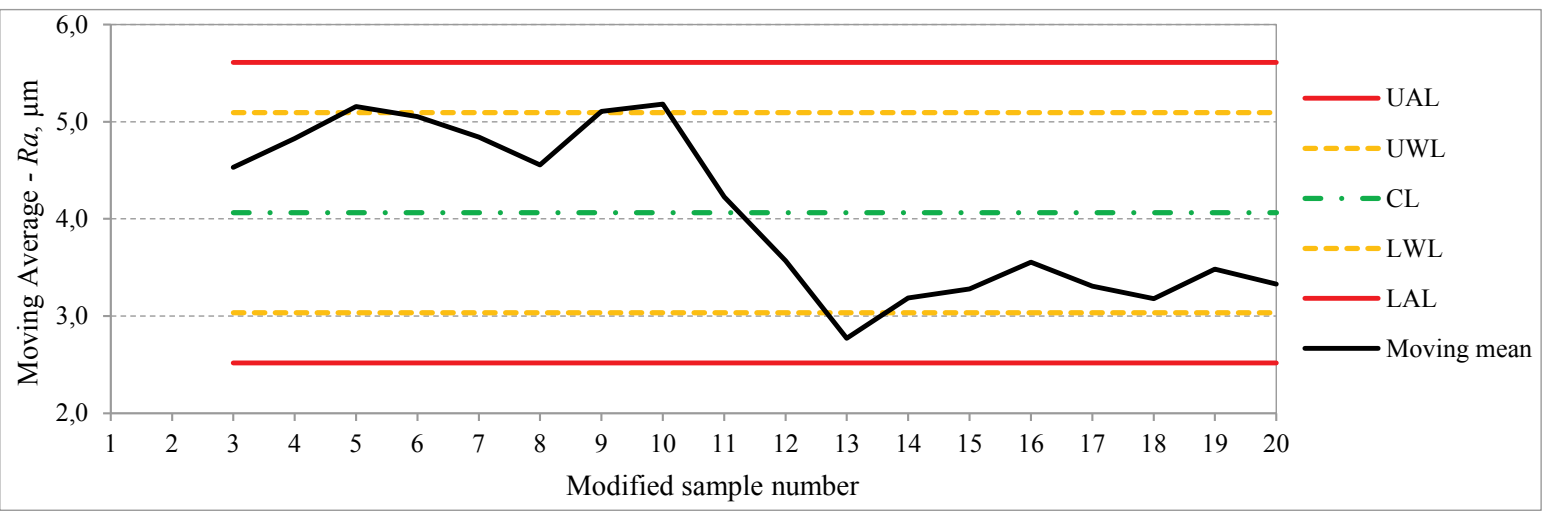

Figure 7 Moving mean chart for $1000 \mathrm{~mm} / \mathrm{min}$ cutting speed and $2000 \mathrm{~W}$ laser power

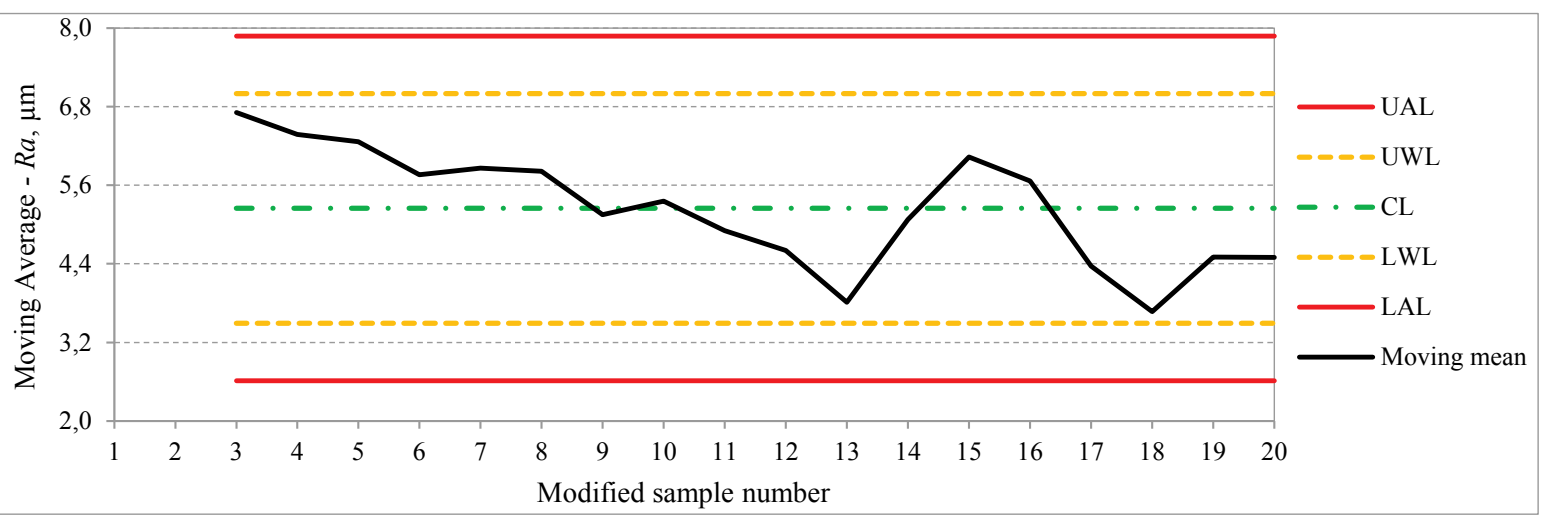

Figure 8 Moving mean chart for $1500 \mathrm{~mm} / \mathrm{min}$ cutting speed and $2000 \mathrm{~W}$ laser power

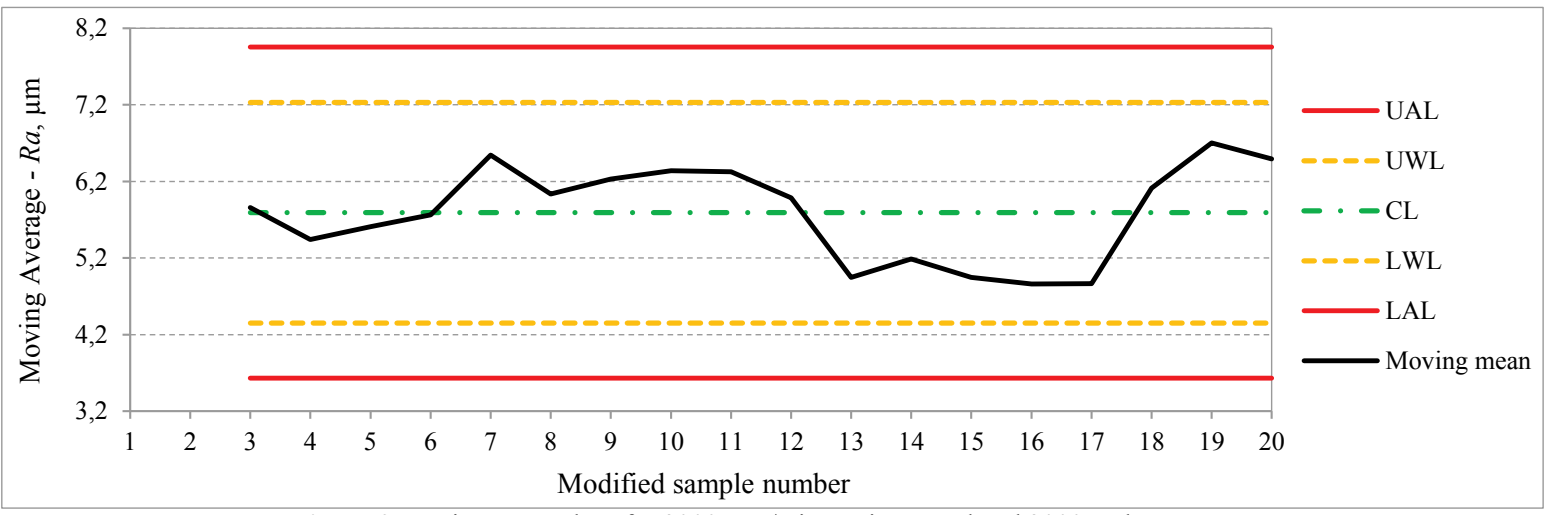

Figure 9 Moving mean chart for $2000 \mathrm{~mm} / \mathrm{min}$ cutting speed and $2000 \mathrm{~W}$ laser power

To summarize, applying the above rules and taking into account statistically expected number of points outside of defined limits, it can be seen that only Figs. 8 and 9, representing using $2000 \mathrm{~W}$ laser power and with cutting speeds $1500 \mathrm{~mm} / \mathrm{min}$ and $2000 \mathrm{~mm} / \mathrm{min}$, show that the process is in control, since there are no points falling outside the action lines limits (both UAL and LAL), there are two successive points outside the warning limits (both UWL and LWL), and there are no continuous eight points at the same side of the mean.

\section{Conclusion}

This research was implemented with the aim to evaluate the laser cutting roughness of the surface of tungsten alloy plate based on different process parameters. Key objective is to obtain combination of the cutting speed and the laser power to achieve stable process and best quality of the cut. In order to find such a combination statistical process control methodology was used. From developed moving mean control charts one can conclude that increase of the cutting speed leads to worsening of process control status for lower laser power used in the experiment. In order to obtain uniform surface roughness along the length of the cut surface during the cutting of the examined alloy using of assist gas nitrogen, $1500 \mathrm{~mm} / \mathrm{min}$ or $2000 \mathrm{~mm} / \mathrm{min}$ cutting speed, with 2000 $\mathrm{W}$ laser power are recommended.

Future work should include application of the statistical process control on analysis of process parameters influence on surface roughness at other cutting processes such as plasma cutting and abrasive water jet cutting of different materials.

\section{Acknowledgements}

This research is supported by the Federal Ministry of Education and Science, Bosnia and Herzegovina. 


\section{References}

[1] Das, J.; Rao, G. A.; Pabi, S. K. Microstructure and Mechanical Properties of Tungsten Heavy Alloys. // Material Science and Engineering A, 527 (2010), pp. 78417847. https://doi.org/10.1016/j.msea.2010.08.071

[2] Wang, Y.; Yang, L. J.; Wang, N. J. An Investigation of Laser-assisted Machining of Al2O3 Particle Reinforced Aluminium Matrix Composites. // Journal of Material Processing Technology, 129 (2002), pp. 268-272. https://doi.org/10.1016/S0924-0136(02)00616-7

[3] Mocnik, D.; Paulic, M.; Klancnik, S.; Balic, J. Prediction of Dimensional Deviation of Workpiece using Regression, ANN and PSO Models in Turning Operation. // Tehnicki vjesnik-Technical Gazette, 21, 1(2014), pp. 55-62.

[4] Venkatesan, K.; Ramanujam, R. Statistical pproach for optimization of influencing parameters in laser assisted machining (LAM) of Inconel alloy. // Measurement, 89 (2016) pp. 97-108. https://doi.org/10.1016/j.measurement.2016.04.021

[5] Schaaf, P. Laser Processing of Materials -fundamentals, applications and developments, Springer Series in Materials Science, 139, Springer, Berlin, 2010.

[6] Petru, J.; Zlamal, T.; Cep, R.; Monkova, K.; Monka, P. Influence of cutting parameters on heat-affected zone after laser cutting. // Tehnicki vjesnik-Technical Gazette, 20, 2(2013), pp. 225-230

[7] Eltawahni, H. A.; Rossini, N. S.; Dassisti, M.; Alrashed, K.; Aldaham, T. A.; Benyounis, K. Y.; Olabi, A. G. Evaluation and optimization of laser cutting parameters for plywood materials. // Optics and Lasers in Engineering, 51 (2013), pp. 1029-1043. https://doi.org/10.1016/j.optlaseng.2013.02.019

[8] Adalarasan, R.; Santhanakumar, M.; Rajmohan, M. Optimization of Laser Cutting Parameters for Al6061/SiCp/Al2O3 Composite using Grey based Response Surface Methodology (GRSM). // Measurement, 73 (2015), pp. 596-606. https://doi.org/10.1016/j.measurement.2015.06.003

[9] Fomin, V. M.; Golyshey, A. A; Malikov, A. G.; Orishich, A. M.; Shulyat'ev, V. B. Mechanical Characteristics of High-Quality Laser Cutting of Steel by Fiber and CO2 Lasers. // Journal of Applied Mechanics and Technical Physics, 56, 4(2015), pp. 726-735. https://doi.org/10.1134/S0021894415040203

[10] Ghavidel, A. K.; Azdast, T.; Shabgard, M. R.; Navidfar, A.; Shishavan, S. M. Effect of carbon nanotubes on laser cutting of multi-walled carbon nanotubes/poly methyl methacrylate nanocomposites. // Optics \& Laser Technology, 67 (2015), pp. 119-124. https://doi.org/10.1016/j.optlastec.2014.10.003

[11] Klancnik, S.; Begic-Hajdarevic, D.; Paulic, M.; Ficko, M.; Cekic, A.; CohodarHusic, M. Prediction of Laser Cut Quality for Tungsten Alloy Using the Neural Network Method. // Strojniski vestnik-Journal of Mechanical Engineering, 61, 12(2015), pp. 714-720. https://doi.org/10.5545/sv-jme.2015.2717

[12] Benneyan, J. C.; Lloyd, R. C.; Plsek, P. E. Statistical Process Control as a Tool for Research and Healthcare Improvement. // QualSaf Health Care, 12 (2003), pp. 458464. https://doi.org/10.1136/qhc.12.6.458

[13] Jalote, P.; Saxena, A. Optimum Control Limits for Employing Statistical Process Control in Software Process. // IEEE Transactions on Software Engineering, 28 (2002), pp. 1125-1133. https://doi.org/10.1109/TSE.2002.1158286

[14] Bakker, A.; Kent, P.; Derry, J.; Noss, R.; Hoyles, C. Statistical Inference at Work: Statistical Process Control as an Example. // Statistics Education Research Journal, 7 (2008), pp. 130-145.
[15] Vucijak, B.; Midzic-Kurtagaic, S.; Ceric, A.; Kupusovic, T.; Spago, S. Assessment of Climate Change Effects to Precipitation Patterns using Statistical Process Control Methods. // Annals of DAAAM for 2012 \& Proceedings of the 23rd Int. DAAAM Symposium, Vienna, 2012, pp. 0277-0280.

[16] Vucijak, B.; Kupusović, T.; Midzic-Kurtagic, S.; Siladzic, I.; Ceric, A. Evaluation of the Climate Change Effects to the Precipitation Patterns in the Selected Bosnia and Herzegovina Cities. // Thermal Science, 18 (2014), pp. 787 798. https://doi.org/10.2298/TSCl1403787V

[17] Begic, D. Experimental and Numerical Analysis of Influential Parameters to the Quality of Cut during Laser Cutting of Metal. PhD thesis, Faculty Mechanical Engineering, Sarajevo University, 2010.

[18] Oakland, J.S. Statistical Process Control, Fifth Edition. Butterworth-Heinemann, An imprint of Elsevier Science, Burlington MA, USA, 2003.

\section{Authors' addresses}

Derzija Begic-Hajdarevic, Assoc. prof. dr. sc. University of Sarajevo

Mechanical Engineering Faculty

Vilsonovo setaliste 9

71000 Sarajevo, Bosnia and Herzegovina

begic@mef.unsa.ba

Branko Vucijak, Assoc. prof. dr. sc. University of Sarajevo

Mechanical Engineering Faculty

Vilsonovo setaliste 9

71000 Sarajevo, Bosnia and Herzegovina

vucijak@mef.unsa.ba

Mugdim Pasic, Prof. dr. sc.

University of Sarajevo

Mechanical Engineering Faculty

Vilsonovo setaliste 9

71000 Sarajevo, Bosnia and Herzegovina

mugdim.pasic@mef.unsa.ba

Izet Bijelonja, Prof. dr. sc.

University of Sarajevo

Mechanical Engineering Faculty

Vilsonovo setaliste 9

71000 Sarajevo, Bosnia and Herzegovina

bijelonja@mef.unsa.ba 